\title{
BCAR4 Gene
}

National Cancer Institute

\section{Source}

National Cancer Institute. BCAR4 Gene. NCI Thesaurus. Code C132177.

This gene may involved in breast cancer metastasis and resistance to antiestrogens. 